\title{
The effect of energy intake on development and reproduction of gilts
}

L. A. den Hartog (Department of Animal Nutrition, Agricultural University, Haagsteeg 4, 6708 PM Wageningen, The Netherlands)

Received 5 October 1984; accepted 10 December 1984

\begin{abstract}
The effect of different energy intakes during rearing on reproductive performance was studied in 680 gilts. An energy intake of 2.5 times maintenance or more is unfavourable, when adequate protein is given, in view of the cost of the feed consumed and the reproductive performance.
\end{abstract}

Key-words: energy, feeding, reproduction, development, gilt, pig.

Introduction. The reproductive rate in gilts and sows is important with regard to their productivity. Considerable variation in the reproductive performance between animals have been observed (den Hartog, 1980). The effects of environment (for example nutrition) are of great importance because of the low heritability of most of the reproductive traits (Legault, 1970). The effects of level of nutrition on reproductive traits have not been studied systematically. There is therefore a need for large-scale experiments, starting early in the life of the pig. The present study focussed on the effect of energy intake of the gilt on reproductive performance.

Material and methods. A total of 680 gilts of the Dutch Landrace from the age of 12 weeks were assigned to one of the four energy levels. The energy levels were about $3 \mathrm{M}, 2.5 \mathrm{M}, 2.1 \mathrm{M}$ and $1.8 \mathrm{M}$ in which $\mathrm{M}$ is the metabolizable energy required for maintenance. The protein allowance was dependent on the weight of the gilts and was similar for all treatments. Each gilt received $2.5 \mathrm{~kg}$ feed per day, from the age of 38 weeks. Gilts without oestrus were induced at the age of 38 weeks. A total of 290 gilts were kept to produce a litter.

Results and discussion. More gilts needed to be culled from the age of 12-38 weeks at the two higher levels of energy intake (16,13, 4 and 8 animals, respectively). Age and weight at first oestrus increased and decreased, respectively, as energy intake during rearing was reduced. The age and weight at first oestrus were 234, 237, 237 and 244 days and 139, 131, 118 and $109 \mathrm{~kg}$, respectively. At the higher level of energy intake, backfat thickness was increased both at a fixed weight of $99 \mathrm{~kg}$ and at a fixed age of 187 days. Regression coefficients of age at puberty on backfat thickness were negative for the two highest levels of energy intake and close to zero for the two lowest energy level groups. Conception rate and percentage of gilts with an oestrus after induction were lower at the two higher levels of energy intake than at the two lower levels $(67,64,76,76$ and $54,68,88,73 \%$, respectively). The number 
of gilts with spontaneous oestrus, embryonic survival, number of piglets born alive, average birth weight and homogeneity of the litter (standard deviation of birth weights within a litter) were not affected by energy intake.

When weight at puberty is corrected towards the same age at puberty, the difference in weight at puberty is increased. It can be concluded therefore that reaching puberty will be determined more by age than by weight within the range of energy supplied. Within feeding levels, backfat thickness was related to age at puberty at the two higher levels but no relationship was found at the low levels. It was concluded that backfat is a threshold for reaching oestrus in animals of young age but is of much less importance in older animals. All the reproductive results were expressed as number of piglets born alive in the first litter per 100 gilts at the start of the experiment. When it is assumed that gilts with no oestrus before the age of 38 weeks or which were not pregnant after first insemination are culled, then the number of piglets born alive were $386,399,437$ and 438, respectively. When results of induced gilts were added these numbers of piglets born alive were $485,486,599$ and 579 , respectively. The difference in number of piglets born alive in the first litter per 100 gilts fed at a high level of energy intake during rearing (2.5 $\mathrm{M}$ or higher) or with a low level of energy intake $(2.1 \mathrm{M}$ or $1.8 \mathrm{M}$ ) was as an average 103 . In this experiment 112 gilts were reallocated to another farm and their lifetime production data were recorded. The different energy intake during rearing did not result in significant differences in number of piglets born in the following litters. Differences in backfat thickness at first parturition had disappeared at parturition of the second litter (Jongbloed et al., 1984, in preparation). Gilts with a high energy intake during rearing had as an average a reduced longevity compared to gilts with a low energy intake (2.1 or $1.8 \mathrm{M}$ ). Nielsen \& Danielsen (1984) also found that gilts on limited diets during rearing were culled later than gilts fed more liberally.

\section{References}

Hartog, L. A. den, 1980. De relatie voeding-uruchtbaarheid bij (opfok)zeugen. Department of Animal Nutrition, Agricultural University, Wageningen, $55 \mathrm{pp}$.

Legault, C., 1970. Etudé statistique et génétique des performances d'élévages des truies de race Large White. II. Effet direct du verrat heritabilité, répétabilité, correlations. Annales de Génétique et de Selection Animale 2:209-227.

Nielsen, H. E. \& V. Danielsen, 1984. Nutrition and breeding lifetime. Proceedings EAAP congress, 6-9 August, The Hague.

This synopsis is based on part of the general discussion in a doctoral thesis entitled 'The effect of energy intake on development and reproduction of gilts and sows', Agricultural University, Wageningen, 1984.117 pp., 13 figs., 42 tables, refs. The major part of this thesis has been published as papers in Netherlands Journal of Agricultural Science.

Available as paper copy (order R024P, $f 30$ including postage) or microfiches (order R024M, f 17.50 including postage) at: NARD, clo Pudoc, P.O. Box 4, 6700 AA Wageningen, The Netherlands (telex 45015 blhwg $\mathrm{nl}$ ). 